\title{
Patho-immune Mechanisms of Hypertension in HIV: a Systematic and Thematic Review
}

\author{
Sepiso K. Masenga ${ }^{1,2,3} \cdot$ Benson M. Hamooya ${ }^{1,4} \cdot$ Selestine Nzala ${ }^{5} \cdot$ Geoffrey Kwenda $^{2} \cdot$ Douglas C. Heimburger $^{3}$. \\ Wilbroad Mutale $^{6} \cdot$ Sody M. Munsaka ${ }^{2} \cdot$ John R. Koethe ${ }^{7}$. Annet Kirabo ${ }^{8,9}$
}

Published online: 4 June 2019

(C) The Author(s) 2019

\begin{abstract}
Purpose of Review To systematically review recent findings on the role of immune cell activation in the pathogenesis of hypertension in people living with HIV (PLWH) and compare studies from Sub-Saharan Africa with what is reported in the USA and European literature according to guidelines of the Preferred Reporting Items for Systematic Reviews and Meta-Analyses.

Recent Findings PLWH have an increased risk for development of hypertension and cardiovascular disease. Chronic immune activation contributes to hypertension but the inflammatory milieu that predisposes PLWH to hypertension is poorly understood. We identified 45 relevant studies from 13 unique African countries. The prevalence of hypertension in PLWH on antiretroviral therapy (ART) and the ART-naive PLWH ranged from 6 to $50 \%$ and 2 to $41 \%$, respectively. Interleukin (IL)-17A, interferon (IFN)- $\gamma$, and higher $\mathrm{CD}^{+}$T cell counts were associated with hypertension in ART-treated participants.

Summary Targeting adaptive immune activation could provide improved care for hypertensive PLWH. Further research is needed to characterize the inflammatory milieu contributing to hypertension in PLWH especially in African populations where the global burden of HIV is the highest.
\end{abstract}

Keywords HIV · Hypertension · Inflammation · Patho-immune mechanisms

\section{Introduction}

The introduction of antiretroviral therapy (ART) has improved survival among people living with HIV (PLWH), but this success is accompanied by a high burden of cardiovascular disease [1-3]. Hypertension is a major risk factor to cardiovascular disease and its prevalence is higher in PLWH despite

This article is part of the Topical Collection on Inflammation and Cardiovascular Diseases

Annet Kirabo

annet.kirabo@vanderbilt.edu

Sepiso K. Masenga

smasenga@mu.ac.zm

1 School of Medicine and Health Sciences, Mulungushi University, Livingstone, Zambia

2 School of Health Sciences, Department of Biomedical Sciences, University of Zambia, Lusaka, Zambia

3 Vanderbilt Institute for Global Health, Nashville, TN, USA

4 School of Public Health, Department of Epidemiology and Biostatistics, University of Zambia, Lusaka, Zambia viral suppression by ART [4]. The mechanisms contributing to hypertension and cardiovascular disease in PLWH are not fully understood.

A heightened systemic inflammatory process including activation of the innate and adaptive immune systems contributes to the development of hypertension in the general population and in experimental animal studies [5-7]. However, it is

5 Department of Medical Education Development, University of Zambia, Lusaka, Zambia

6 School of Public Health, Department of Health policy and Management, University of Zambia, Lusaka, Zambia

7 Division of Infectious Diseases, Vanderbilt University Medical Center, Nashville, TN, USA

8 Department of Medicine, Division of Clinical Pharmacology, Vanderbilt University Medical Center, 2215 Garland Avenue, P415C Medical Research Building IV, Nashville, TN 37232, USA

9 Department of Molecular Physiology and Biophysics, Vanderbilt University, Nashville, TN, USA 
unknown which innate and adaptive immune factors are most closely linked to hypertension in PLWH. At present, much of our understanding of the role of immune cell activation in the pathogenesis of hypertension comes from experimental animal and human studies in the HIV-negative context, but similar inflammatory biomarkers implicated in these HIVnegative studies have also been associated with hypertension in HIV infection. In this review, we present the current understanding on HIV, hypertension, and immune activation and how these may be related and highlight gaps and the need for further studies. We review studies conducted in SubSaharan Africa where the global HIV infection burden is the highest. We also performed a comparative analysis contrasting studies from Sub-Saharan Africa with what is reported in the USA and European literature.

The aim of our current study was to estimate the prevalence of hypertension in PLWH from African studies, identify inflammatory markers or markers of immune activation associated with hypertension in antiretroviral (ART)-treated HIVpositive individuals, and to explore the possible mechanistic interaction between immune activation, hypertension, and HIV in cohorts from Sub-Saharan Africa and contrast with European and US cohorts.

\section{Methods}

We followed guidelines of the Preferred Reporting Items for Systematic Reviews and Meta-Analyses (PRISMA) [8, 9].

Eligibility Criteria for Studies Included in the Review We considered studies on HIV-positive human subjects with or without the HIV-negative population as controls. For exposure and outcome variables, we considered HIV infection as the exposure and our outcome measures were hypertension or blood pressure, inflammation, and/or immune activation. Only published articles in peer-reviewed journals were considered. Articles in languages other than English were not considered. We only included studies from Sub-Saharan African, USA, and European HIV-positive populations that reported on hypertension and HIV excluding studies that did not report HIV at all. We also excluded studies reporting opportunistic infections and other coinfections to reduce bias when deducting on the contribution of HIV on hypertension. In case of duplicate publications, the article with more complete data was included. Extracted information focused on study design, population, sample size, country where study was conducted, and details of findings with conclusions. The source of research articles was derived from Pubmed, Medline, google scholar, and google search. Dates of coverage were not specified to filter studies addressing hypertension and inflammation or immune activation in HIV owing to the scarcity of published studies. Other articles were identified from reference lists of related studies from the included study. Search terms that were used in databases employed the use of Boolean operators "AND," "OR," and "NOT" to refine our search by combining or limiting terms. The key terms used to search for articles were "hypertension," "blood pressure," "immune activation," "inflammation," "Africa," and "HIV."

Studies were screened based on abstract information that reported HIV or/and inflammation or immune activation and hypertension or blood pressure. A full article was then obtained and screened to ensure eligibility. The PRISMA 2009 Flow Diagrams for article identification, screening, eligibility, and inclusion in Sub-Saharan African and the Western populations are shown in Supplementary Figures 1 and 2 found at the following link: https://figshare.com/s/ 38ff86137d00153423ac. For data extraction, we used a data collection form that identifies the author, study, population, sample size, methods, findings, and limitations.

Risk of bias was assessed by two reviewers. For the criteria used to assess internal validity of included studies, we made use of the Cochrane Risk of Bias tool, paying attention especially to parts such as completeness of outcome data, selective outcome reporting, reporting bias, and any other bias that may affect the exposure-outcome relationship. For any disagreements between the reviewers over the risk of bias in particular studies, this was resolved by discussion, with involvement of a third review author where necessary.

Data Synthesis We did not conduct a meta-analysis. We only conducted a systematic thematic review due to the qualitative nature of our study and due to excessive heterogeneity of population, outcome, or methodology. To assist with the result and discussion write-ups, we constructed summary tables and provided a narrative synthesis (thematic or content analysis). This includes investigation of the similarities and the differences between the findings of different studies, as well as exploration of patterns in the data. Reasons for similarities and differences in the findings were also explored systematically. Studies were grouped based on reported parameters. We also considered how the results of studies might be affected by factors such as methodological differences, variable characteristics of the populations studied, or interventions investigated. Conceptual models were used to explore relationships and patterns from study findings and we related the findings to existing concepts from animal models to generate hypotheses and the need for further studies.

\section{Results}

Characteristics of the Studies We performed a systematic review of studies on HIV, hypertension, and immunity from countries in Sub-Saharan Africa, USA, and Europe. For Sub-Saharan Africa studies shown in Table 1, we included 
Table 1 Characteristics of studies included in the Sub-Saharan African studies

\begin{tabular}{ll}
\hline Study characteristics & Number $(n)$ or percentage (\%) \\
\hline Number of studies included & 45 \\
Number of African countries where the studies were conducted & 13 \\
Number of types of studies & 3 \\
Studies reporting on inflammation plus hypertension plus HIV only & 5 \\
Studies reporting on hypertension plus HIV only & 35 \\
Studies reporting on HIV plus immune activation/inflammation & 5 \\
Studies reporting on inflammation plus hypertension in African populations & 0 \\
Overall prevalence of HTN in PLWH on ART (\% range) & $6.4-50.2$ \\
Overall prevalence of HTN in ART-naive PLWH (\% range) & $2-41$ \\
Overall prevalence of HTN in HIV-negative population (\% range) & $13.7-44$ \\
HTN prevalence percentage differences within studies, range (| magnitude $)$ & \\
PLWH on ART minus ART naive & -12.3 to $23.4(|35.7|)$ \\
PLWH on ART minus HIV negative & -6.3 to $12.4(|18.7|)$ \\
HIV negative minus ART naive & -5.3 to 11 (| 16.3|)
\end{tabular}

HTN, hypertension; HIV, human immune deficiency virus; ART, antiretroviral therapy; PLWH, people living with HIV

45 studies from 13 countries. Of the 45 studies, 27 were crosssectional, 15 were prospective, and three were retrospective. Most of the studies (35) reported on both hypertension and HIV. The prevalence of hypertension was highest in the HIVpositive group on ART (ranging from 6.4 to $50.2 \%$ ) followed by HIV-negative controls (13.7 to $44 \%$ ). ART-naive patients recorded the lowest prevalence ranging from 2 to $41 \%$ by group comparisons. The prevalence differences of groups within studies were highest between ART treated and ARTnaive HIV-positive groups (35.7) followed by ART treated and HIV-negative group (18.7) with the least difference in magnitude between HIV negative and ART-naive groups.

When we included USA and European studies, shown in Supplementary Table 1 found at the following link: https:// figshare.com/s/38ff86137d00153423ac, the global prevalence of hypertension in PLWH ranged from 4 to $57 \%$ (van Ziest et al. 2017) [10]. Hypertension was more prevalent in HIV uninfected (71\%) versus HIV infected $(57 \%)$ in a large longitudinal study by Armah et al. [11]. HIV-infected veterans with HIV-1 RNA $\geq 500$ copies/mL or CD4 count $<200$ cells/ $\mu \mathrm{L}$ had a significantly higher prevalence of elevated IL-6 and D-dimer after adjusting for comorbidities and had significantly higher prevalence of elevated sCD14 compared to uninfected veterans. Manner et al. [12] reported prevalence of $35 \%$ hypertension in HIV-infected individuals and the prevalence did not change during the follow-up time ( $3.4 \pm 0.8$ years). CD4 $\mathrm{T}$ cell count $<50$ cells $/ \mu \mathrm{L}$ and increased duration of ART were independent predictors of sustained hypertension throughout the study period. Older age, male gender, BMI > $25 \mathrm{~kg} / \mathrm{m}^{2}$, and baseline CD4 cell count $\geq 200$ cells $/ \mu \mathrm{L}$ were also independent predictors of sustained hypertension. Markers of microbial translocation predicted hypertension in HIV-infected individuals. Manner et al. found that both LPS and sCD14 independently predicted subsequent blood pressure levels after adjustment for age and gender [12]. These results suggest that ART may act as a contributing factor to inflammation and the increased prevalence of hypertension in the PLWH.

Higher Levels of IL-17A, IFN- $\gamma$, and CD4 ${ }^{+}$T Cells Are Associated with Hypertension in HIV We found that among studies reporting on both inflammation, immunity, and hypertension in HIV (Table 2), higher levels of IL-17A, IFN- $\gamma$, [13••], and CD4 ${ }^{+}$T cell count (Peck et al.) [4] were significantly associated with hypertension in ART treated HIV-positive individuals. The cross-section study by Chepchirchir et al. reported that females were more likely to have higher IL-17A levels than males and IL-17A was affected by BMI but not stress levels, ART, World Health Organization (WHO) stage, and CD4 ${ }^{+}$ count $[13 \bullet \bullet]$. However, inflammatory cytokines IL-2, IL-6, IL-8, tumor necrosis factor alpha (TNF- $\alpha)$, and antiinflammatory cytokines IL-4 and IL-10 were not associated with hypertension. The cross-section study by Peck et al. reported higher cases of hypertension among PLWH on ART [28.7\% (43/150)] compared to ART-naive participants $[5.3 \%$ (8/151)]; however, the prevalence was higher in HIV-negative patients [16.3\% (25/153)] compared to ART-naive HIV-positive patients. The inflammatory markers, C-reactive protein (CRP), and IL-6 in the prospective study by Fourie et al. where the three participant groups had comparable blood pressures did not differ between HIV positive on ART, ART naive, and HIVnegative groups. In another prospective study by Okello et al., blood pressure increases were reported in the first 6 months of ART initiation then plateaued. Traditional risk factors including older age, male gender, African-American, higher body mass index (BMI), central obesity, previous cardiovascular events, 
Table 2 Characteristics and findings of studies reporting on inflammation, hypertension, and HIV

\begin{tabular}{|c|c|c|c|c|}
\hline Author/ & $\begin{array}{l}\text { Type of study, } \\
\text { country, and } \\
\text { population }\end{array}$ & $\begin{array}{l}\text { Sample size and } \\
\text { subjects }\end{array}$ & Key findings & Limitations/notes/conclusion \\
\hline $\begin{array}{l}\text { Chepchirchir } \\
\text { et al. } 2018 \\
{[13 \bullet \bullet}\end{array}$ & $\begin{array}{l}\text { Cross-section } \\
\text { study } \\
\text { conducted in } \\
\text { Kenya among } \\
\text { PLHIV }\end{array}$ & $\begin{array}{l}126 \text { HIV-positive with } \\
\text { and without } \\
\text { hypertension }\end{array}$ & $\begin{array}{l}\text { • HTN prevalence was } 23.2 \% \\
\text { • IL-17A was associated with hypertension in } \\
\text { HIV }\{\text { HTN } 75.51 \pm 84.89 \text { versus } \\
\text { normotensives } 42.23 \pm 64.40 \text {; CI } \\
6.81-59.77, p<0.001 \text { and females were } \\
\text { more likely to have higher IL-17A levels } \\
\text { than males in HIV }(p<0.001) \\
\text { - IL-17A was affected by BMI } \\
r(124)=0.223 p=0.070 \text { but not stress } \\
\text { levels, ART, WHO stage and CD4+ count } \\
\text { - IFN- } \gamma \text { HTN } 6.87 \pm 35.66 \text {; normotensives } \\
0.00 \pm 0.00 \text { CI }-1.96-15.71, p=0.003\} \\
\text { correlated negatively with hypertension } \\
\text { status }\left(r_{\mathrm{s}}=-0.217, p<0.015\right) \\
\text { - IL-4,-2,-6,- } 8,-10, \text { TNF } \alpha \text { were not } \\
\text { associated with hypertension }\end{array}$ & $\begin{array}{l}\text { - Monitoring and analysis of cytokine } \\
\text { expression may help to predict patients' } \\
\text { pathways in their response to cART } \\
\text { therapy and risk of metabolic disorders } \\
\text { - IFN } \gamma \text { is potentially useful in determining } \\
\text { risk of developing hypertension in this } \\
\text { population } \\
\text { - Mechanism of interaction between } \\
\text { hypertension and inflammation or } \\
\text { immune activation not very explicit }\end{array}$ \\
\hline $\begin{array}{l}\text { Peck et al. } \\
2014 \\
{[14 \bullet \bullet]}\end{array}$ & $\begin{array}{l}\text { Cross-sectional } \\
\text { study } \\
\text { conducted in } \\
\text { Tanzania } \\
\text { among PLHIV }\end{array}$ & $\begin{array}{l}454 \text { participants: HIV+ } \\
\text { on ART, ART-naive } \\
\text { HIV+ and } \\
\text { HIV-negative } \\
\text { controls }\end{array}$ & $\begin{array}{l}\text { - Prevalence of HTN in HIV negative was } \\
16.3 \%(25 / 153) \\
\text { - Prevalence of HTN in HIV+ on ART was } \\
28.7(43 / 150) \text { was the highest }(p=0.01) \\
\text { among the groups with higher odds HTN } \\
\text { even after adjustment (odds ratio } \\
\text { (OR) }=2.19(1.18 \text { to } 4.05), p=0.01) \\
\text { - Prevalence of HTN in ART-naive HIV+ } \\
\text { was } 5.3 \%(8 / 151) \text {, and lowest among } \\
\text { group ( } p=0.003) \text { with lower odds of } \\
\text { HTN even after adjustment (OR = } 0.35 \\
(0.15 \text { to } 0.84), p=0.02) \\
\text { - The prevalence HTN was lowest in group } \\
\text { with the lowest average CD4+ T cell count } \\
\text { (HIV-infected ART naive) and highest in } \\
\text { the group in which the CD4+ T cell count } \\
\text { had been low and had then been } \\
\text { reconstituted in the setting of ART } \\
\text { - In the HIV+ group, higher CD4+ T cell } \\
\text { counts were associated with more } \\
\text { hypertension and higher blood pressures } \\
\text { - Age, vigorous work, current alcohol use, } \\
\text { and BMI were all associated with } \\
\text { hypertension } \\
\text { - Anly PI use was associated with HTN } \\
75 \% \text { were undiagnosed, } 85 \% \text { were } \\
\text { untreated, and }>95 \% \text { were uncontrolled }\end{array}$ & $\begin{array}{l}\text { - HIV-infected adults with hypertension } \\
\text { were rarely aware of their diagnosis but } \\
\text { often have evidence of kidney disease } \\
\text { - It was unknown whether chronic } \\
\text { inflammation accelerates HTN } \\
\text { - High prevalence of hypertension among } \\
\text { HIV-infected adults on ART could be } \\
\text { related to dysregulated inflammation due } \\
\text { to immune reconstitution } \\
\text { - Mechanism of interaction between } \\
\text { hypertension and inflammation or } \\
\text { immune activation not explicit }\end{array}$ \\
\hline $\begin{array}{l}\text { Fourie et al. } \\
2015[15]\end{array}$ & $\begin{array}{l}\text { Prospective study } \\
\text { conducted in } \\
\text { South Africa }\end{array}$ & $\begin{array}{l}309 \text { participants: } \\
66 \text { HIV+ on ART, } \\
78 \text { (ART-naive HIV+ } \\
\text { and165 } \\
\text { HIV-negative } \\
\text { controls }\end{array}$ & $\begin{array}{l}\text { - The inflammatory markers (CRP and IL-6) } \\
\text { did not differ between the three groups } \\
\text { - Endothelial activation was not } \\
\text { accompanied by increased inflammation } \\
\text { - BP comparable among groups }\end{array}$ & $\begin{array}{l}\text { - Mechanism of interaction between } \\
\text { hypertension and inflammation or } \\
\text { immune activation not explicit } \\
\text { - Several cytokines not reported }\end{array}$ \\
\hline $\begin{array}{l}\text { Okello et al. } \\
2016[16]\end{array}$ & $\begin{array}{l}\text { Prospective } \\
\text { cohort study } \\
\text { conducted in } \\
\text { Uganda }\end{array}$ & $\begin{array}{l}536 \text { HIV positive } \\
\text { initiating ART }\end{array}$ & $\begin{array}{l}\text { - Systolic BP increased by } 9.6 \mathrm{mmHg} / \text { year } \\
\text { (95\% CI 7.3-11.8) in the first } 6 \text { months of } \\
\text { ART, then plateaued } \\
\text { - Male gender, overweight, and a CD4 count } \\
<100 \text { cells were associated with incident } \\
\text { hypertension }\end{array}$ & $\begin{array}{l}\text { - Blood pressure increases early after ART } \\
\text { initiation in Ugandans. Traditional risk } \\
\text { factors, rather than immune activation } \\
\text { were associated with incident } \\
\text { hypertension in this population } \\
\text { - Only sCD14, sCD163 (immune activation } \\
\text { markers), and IL-6 (inflammatory } \\
\text { marker) were examined }\end{array}$ \\
\hline
\end{tabular}


Table 2 (continued)

\begin{tabular}{|c|c|c|c|c|}
\hline Author/ & $\begin{array}{l}\text { Type of study, } \\
\text { country, and } \\
\text { population }\end{array}$ & $\begin{array}{l}\text { Sample size and } \\
\text { subjects }\end{array}$ & Key findings & Limitations/notes/conclusion \\
\hline & & & & $\begin{array}{l}\text { Mechanism of interaction between } \\
\text { hypertension and inflammation or } \\
\text { immune activation not explicit }\end{array}$ \\
\hline $\begin{array}{c}\text { Borkum et al. } \\
2017 \text { [17] }\end{array}$ & $\begin{array}{l}\text { Cross-sectional } \\
\text { study } \\
\text { conducted } \\
\text { among South } \\
\text { African blacks }\end{array}$ & $\begin{array}{l}67 \text { HIV-positive } \\
\text { participants on ART } \\
>5 \text { years }\end{array}$ & $\begin{array}{l}\text { - Prevalence of non-dipping BP was } 65 \% \\
\text { - High levels of inflammation (hsCRP) } \\
\text { - There was no association on multivariable } \\
\text { analysis between dipping status and } \\
\text { traditional risk factors for non-dipping BP, } \\
\text { such as obesity, autonomic dysfunction, } \\
\text { and older age }\end{array}$ & $\begin{array}{l}\text { - } 91 \%(n=61) \text { were females } \\
\text { - Inflammation was only assessed using } \\
\text { hsCRP } \\
\text { - Mechanism of interaction between } \\
\text { hypertension and inflammation or } \\
\text { immune activation not explicit }\end{array}$ \\
\hline
\end{tabular}

PLHIV, people living with HIV; HTN, hypertension; HIV, human immunodeficiency virus; BP, blood pressure; CRP, C-reactive protein; ART, antiretroviral therapy; PI, protease inhibitors; IL, interleukin; BMI, body mass index; CI, confidence interval; TNF $\alpha$, tumor necrosis factor alpha; IFN $\gamma$, interferon gamma; WHO, World Health Organization; cART, combinational ART; sCD14, soluble CD14; sCD163, soluble CD163; hsCRP, highsensitivity C-reactive protein

chronic kidney disease, family history of hypertension and cardiovascular disease, diabetes, and dyslipidemia rather than immune activation were associated with incident hypertension in this study. Borkum et al. reported high levels of inflammation and non-dipping blood pressure [14••].

Prevalence of Hypertension Is Higher in ART-Treated PLWH As shown in Table 3, hypertension prevalence was mostly higher in men than women [15-17] and higher among ART treated versus ART naive $(28.7 \%$ vs $5.3 \% ; 17 \%$ vs $2 \% ; 30$ vs $21.9 \%$ and $38 \%$ vs $19 \%$, respectively) $[17,18]$. However, one study [22] reported contradictory findings (ART vs ART naive, 12.3 vs 19\%). In another study, [17] reported higher prevalence of hypertension in ART treated group (28.7\%) compared to the HIV-negative controls $(16.3 \%)$ but two studies $[22,25]$ reported the opposite ( $41 \%$ vs $44 \%$ and $12.3 \%$ vs $13.7 \%$, respectively). Peck et al. reported higher prevalence of hypertension in HIV negative vs ART-naive HIV-positive group (16.3\% vs $5.3 \%$ ) [17]. On the contrary, Ogunmola et al. reported lower prevalence of hypertension in HIV negative vs ART-naive HIVpositive group (13.7\% vs 19\%, respectively). Association between hypertension and traditional risk factors including specific ART regimens varied between studies.

ART Treatment in PLWH Is Associated with Higher Inflammation As shown in Table 4, we found that PLWH on ART had higher inflammatory markers including IL-6, CRP, intracellular adhesion molecule 1 (ICAM-1), and vascular adhesion molecule 1 (VCAM-1) compared with HIV-negative individuals (Fourie et al.) [55]. Intermediate monocytes $\left(\mathrm{CD} 14^{+} 16^{+}\right)$increased with viremia in immunecompromised patients and microbial translocation was a major force driving chronic systemic inflammation in HIVpositive individuals on ART.

\section{Discussion}

In the current study, we found that the prevalence of hypertension in PLWH in Sub-Saharan African countries ranged from 2.0 to $50.2 \%$ with most cases among those receiving ART. Besides traditional risk factors and the effect of ART on blood pressure, IL-17A, IFN- $\gamma$, and $\mathrm{CD} 4^{+} \mathrm{T}$ cells were among the inflammatory parameters associated with hypertension in ART treated PLWH [13••, 56]. The mechanism of interaction between immune activation or inflammation and hypertension in HIV remains elusive and warrants further studies. Our findings and conceptual hypothesis of how immune activation may contribute to hypertension in HIV is shown in Fig. 1. We propose that HIV viral protein and ART interacts with components of the immune system to synergistically induce kidney damage, vascular dysfunction, alterations in sympathetic nervous outflow and lead to hypertension. This process is exacerbated by presence of traditional risk factors exacerbates including obesity, excess dietary salt intake, smoking, and genetic predisposition.

\section{Prevalence of Hypertension in HIV}

The prevalence of hypertension in PLWH varies by population and subgroups even within the same countries. Similar to our findings, Martin-Iguacel et al. and Nguyen et al. reported prevalence ranging from 4 to $54 \%$ [57••] and 8.7 to $45.9 \%$ among PLWH in low- and middle-income countries [58]. However, in our study, we further segregated prevalence by HIV infection and ART treatment and report magnitude of differences between the groups (Table 1). Higher hypertension prevalence was reported in ART treated PLWH compared with ART-naive participants except in the study by Ogunmola et al. who reported the opposite [22]. This 
Table 3 Characteristics and findings of studies reporting on hypertension and HIV

\begin{tabular}{|c|c|c|c|c|}
\hline Author/ & $\begin{array}{l}\text { Type of study, country and } \\
\text { population }\end{array}$ & $\begin{array}{l}\text { Sample size and } \\
\text { subjects }\end{array}$ & Key findings & Limitations/notes/conclusion \\
\hline $\begin{array}{l}\text { Bloomfield et al. } \\
\quad 2011[18]\end{array}$ & $\begin{array}{l}\text { Retrospective study conducted } \\
\text { in Kenya among PLWH }\end{array}$ & $\begin{array}{l}\text { 12,194 } \\
\text { HIV-positive } \\
\text { participants }\end{array}$ & $\begin{array}{l}\text { - HTN prevalence among men } 11.2 \% \\
\text { and women } 7.4 \% \text {, overall } 8.7 \% \\
\text { - Age, overweight/obesity, longer } \\
\text { duration on PI were not associated } \\
\text { with HTN } \\
\text { - HTN more common in younger } \\
\text { HIV vs older } \\
\text { - Higher HTN cases associated with } \\
\text { patients with higher CD4 in men } \\
\text { than women but blunted HTN } \\
\text { occurred with older age }\end{array}$ & $\begin{array}{l}\text { Immune mechanisms not } \\
\text { addressed explicitly }\end{array}$ \\
\hline Julius et al. 2011 [19] & $\begin{array}{l}\text { Cross-sectional study conducted } \\
\text { in South Africa among PLWH } \\
\text { on ART }\end{array}$ & 304 & $\begin{array}{l}\text { Prevalence of HTN was } 19.1 \% \text {. } \\
23.9 \% \text { in men and } 17.7 \% \text { in } \\
\text { women }(95 \% \text { confidence interval } \\
\text { (CI) } 14.7-23.5), p=0.10)\end{array}$ & $\begin{array}{l}\text { Immune mechanism not } \\
\text { addressed }\end{array}$ \\
\hline Diouf et al. 2012 [20] & $\begin{array}{l}\text { Cross-section study conducted } \\
\text { in Senegal among PLWH }\end{array}$ & $242 \mathrm{HIV}$ & $\begin{array}{l}\text { - } 28.1 \% \text { had hypertension } \\
\text { - ART duration not associated with } \\
\text { HTN } \\
\text { - Longer exposure to LPV/r was } \\
\text { associated with a reduced risk of } \\
\text { hypertension }\end{array}$ & $\begin{array}{l}\text { Higher hypertension observed } \\
\text { for male patients with CD4 } \\
\text { count above } 200 \text { cells } / \mu \mathrm{L} \text {, but } \\
\text { differences were not } \\
\text { statistically significant }\end{array}$ \\
\hline $\begin{array}{l}\text { Ngatchou et al. } 2013 \\
\text { [21] }\end{array}$ & $\begin{array}{l}\text { Cross-sectional study conducted } \\
\text { in Cameroon among PLWH }\end{array}$ & $\begin{array}{l}204 \text { participants } \\
\text { consisting of } \\
108 \text { HIV ART } \\
\text { naive vs } 96 \text { HIV } \\
\text { negative }\end{array}$ & $\begin{array}{l}\text { Prevalence of HTN in HIV was } 41 \% \\
\text { and HIV negative } 44 \%\end{array}$ & $\begin{array}{l}\text { Immune mechanism or } \\
\text { inflammation as it relates to } \\
\text { hypertension was not } \\
\text { addressed }\end{array}$ \\
\hline $\begin{array}{l}\text { Parikh et al. } 2013 \\
\text { [22] }\end{array}$ & $\begin{array}{l}\text { Cross-sectional study conducted } \\
\text { in Uganda and Zimbabwe } \\
\text { among PLWH }\end{array}$ & 3316 & $\begin{array}{l}\text { Prevalence of systolic and diastolic } \\
\text { hypertension was } 21.3 \% \text { and } \\
19.0 \% \text { for older adults; and } 9.2 \% \\
\text { and } 3.5 \% \text { for younger adults with } \\
\text { HIV (both, } p<0.001 \text { ) }\end{array}$ & $\begin{array}{l}\text { Immune mechanism or } \\
\text { inflammation as it relates to } \\
\text { hypertension was not } \\
\text { addressed }\end{array}$ \\
\hline Ekali et al. 2013 [23] & $\begin{array}{l}\text { Cross-sectional study conducted } \\
\text { in Cameroon among PLWH }\end{array}$ & 143 & $\begin{array}{l}\text { SBP and DBP increased with } \\
\text { duration on ART. HTN was } \\
\text { associated with longer duration on } \\
\text { ART }\end{array}$ & $\begin{array}{l}\text { Immune mechanism or } \\
\text { inflammation as it relates to } \\
\text { hypertension was not } \\
\text { addressed }\end{array}$ \\
\hline $\begin{array}{l}\text { Muhammad et al. } \\
2013 \text { [24] }\end{array}$ & $\begin{array}{l}\text { Cross-sectional study conducted } \\
\text { in Nigeria among PLWH }\end{array}$ & $\begin{array}{l}200 \text { HIV+ ART } \\
\text { and ART-naive } \\
\text { participants }\end{array}$ & $\begin{array}{l}\text { HTN prevalence was } 17 \% \text { in ART } \\
\text { and } 2 \% \text { in ART naive }(p<0.001) \\
\text { HAART was associated with HTN }\end{array}$ & $\begin{array}{l}\text { Immune mechanism or } \\
\text { inflammation as it relates to } \\
\text { hypertension was not } \\
\text { addressed }\end{array}$ \\
\hline $\begin{array}{l}\text { Mateen et al. } 2013 \\
\text { [25] }\end{array}$ & $\begin{array}{l}\text { Cross-sectional study conducted } \\
\text { in Uganda among PLWH } \\
\text { initiating ART }\end{array}$ & 5563 & HTN prevalence was $27.9 \%$ & $\begin{array}{l}\text { Immune mechanism or } \\
\text { inflammation as it relates to } \\
\text { hypertension was not } \\
\text { addressed }\end{array}$ \\
\hline $\begin{array}{l}\text { Botha et al. } 2014 \\
\text { [26] }\end{array}$ & $\begin{array}{l}\text { Prospective study conducted in } \\
\text { South Africa among PLWH }\end{array}$ & $\begin{array}{l}137 \text { participants: } \\
66 \text { HIV+ on } \\
\text { ART and } 71 \\
\text { HIV+ } \\
\text { ART-naive } \\
\text { participants }\end{array}$ & $\begin{array}{l}\text { HIV+ on ART had higher pulse } \\
\text { pressure }(13.3 \% ; p=0.004), \\
\text { systolic blood pressure }(4.5 \% \\
p=0.029), \text { and CD4 cell count } \\
(9.2 \% ; p=0.009) \text { levels over } \\
5 \text { years }\end{array}$ & $\begin{array}{l}\text { Immune mechanism or } \\
\text { inflammation as it relates to } \\
\text { hypertension was not } \\
\text { addressed }\end{array}$ \\
\hline $\begin{array}{l}\text { Ogunmola et al. } \\
2014 \text { [27] }\end{array}$ & $\begin{array}{l}\text { Cross-section conducted in } \\
\text { Nigeria among PLWH }\end{array}$ & $\begin{array}{l}403 \text { participants. } \\
\text { Groups: } \\
\text { HIV-negative } \\
\text { controls, HIV+ } \\
\text { on ART, and } \\
\text { ART-naive } \\
\text { HIV+ }\end{array}$ & $\begin{array}{l}\text { - Prevalence was } 13.7 \% \text { in HIV } \\
\text { negative, } 19.0 \% \text { in HIV+ ART } \\
\text { naive, and } 12.3 \% \text { in HIV-positive } \\
\text { ART subjects } \\
\text { - Multivariate regression analysis } \\
\text { showed no relationship between } \\
\text { hypertension and HIV status } \\
(p=0.293) \text { or ART status } \\
(p=0.587) \text { but only with BMI }\end{array}$ & $\begin{array}{l}\text { Immune mechanism or } \\
\text { inflammation as it relates to } \\
\text { hypertension was not } \\
\text { addressed }\end{array}$ \\
\hline $\begin{array}{l}\text { Shaffer et al. } 2014 \\
\text { [28] }\end{array}$ & $\begin{array}{l}\text { Prospective study; randomized, } \\
\text { open-label ART trials among }\end{array}$ & 741 & $\begin{array}{l}\text { Over } 144 \text { weeks NVP compared to } \\
\text { LPV/r group had greater mean }\end{array}$ & $\begin{array}{l}\text { Immune mechanism or } \\
\text { inflammation as it relates to }\end{array}$ \\
\hline
\end{tabular}


Table 3 (continued)

\begin{tabular}{ll}
\hline Author/ & $\begin{array}{l}\text { Type of study, country and } \\
\text { population }\end{array}$ \\
& 7 African countries (South \\
& Africa; Kenya; Zimbabwe, \\
& Botswana, Zambia, Malawi, \\
and Uganda)/population & included HIV+ women only \\
with immunocompromised & $\mathrm{CD}<200$
\end{tabular}

Sawadogo 2014 [29] Cross-sectional study conducted 400 participants in Burkina Faso among PLWH on ART

Kagaruki et al. 2014 Cross-section study conducted [30] in Tanzania

Abrahams et al. 2015 Prospective study from South [31] Africa in HIV+ women

Okello et al. 2015 Prospective study in Uganda [32] subjects

Sample size and Key findings

increases in BP (diastolic BP $22.7 \%$ vs. $6.5 \%$ )

Hypertension prevalence was $12.0 \%$

671 participants HIV+ on ART and ART naive

103 participants

3389 participants; HIV+ initiating ART

- $13 \%$ incidence of HTN
Limitations/notes/conclusion

hypertension was not addressed
- The prevalence of hypertension was $26.2 \%$ and was high among those on ART (30.0\% vs $21.9 \%$, $p=0.010)$

- Aged $>40$ years $(\mathrm{AOR}=2.52,95 \%$ CI 1.37-4.63), abnormal waist circumference $(\mathrm{AOR}=2.3795 \%$ CI 1.13-5.00), overweight/obesity $(\mathrm{AOR}=2.71,95 \%$ CI 1.26-5.84), and male sex $(\mathrm{AOR}=1.17$, 1.02-4.20) were the predictors of hypertension among patients on ART while raised total cholesterol $(\mathrm{AOR}=1.47(1.01-2.21)$ and being aged $>40$ years $(\mathrm{AOR}=3.42,95 \%$ CI 2.06-5.70) were predictors for hypertension among ART-naive patients

- Systolic and diastolic blood pressure increased significantly and the proportion of participants with hypertension increased from 3.9 to $15.5 \%(p<0.001)$

- Long-term exposure to ART, increased in hypertension

- Stavudine and efavirenz and nevirapine were significantly associated with hypertension

- Male gender (AHR 1.88, 95\% CI 1.49-2.39), increasing age (AHR $1.36,95 \%$ CI $1.02-1.82$ for those $>40$ years compared to those aged 30 years or less), nadir CD4 count (AHR 0.77, 95\% CI 0.60-0.99 and AHR $0.6495 \%$ CI $0.41-1.00$ for a nadir CD4 cell count 100-350 and $>350$ cells $/ \mathrm{mm}^{3}$ compared to $<100$ cell $/ \mathrm{mm}^{3}$, respectively), and high baseline body mass index (AHR 2.50, 95\% CI 1.56-4.01 for those with a BMI $\geq 30 \mathrm{~kg} / \mathrm{m}^{2}$ versus normal $\mathrm{BMI}$ ) were independently associated with increased risk of hypertension

- Neither use of TDF versus AZT, nor use of NVP versus EFV was associated with risk of hypertension in the multivariate model
- Results are the first to document high rates incident hypertension during longitudinal follow-up among initially normotensive PLHIV initiating ART

- Particularly notable was the magnitude of hypertension incidence in younger groups

- Potential mechanisms for increased incidence of hypertension postulated in this paper include HIV-associated chronic inflammation, immune suppression, endothelial activation, and dysfunction, as well as the direct infection of arterial vascular smooth muscle cells by HIV

- Alternatively, incident hypertension in this setting 
Table 3 (continued)

\begin{tabular}{|c|c|c|c|c|}
\hline Author/ & $\begin{array}{l}\text { Type of study, country and } \\
\text { population }\end{array}$ & $\begin{array}{l}\text { Sample size and } \\
\text { subjects }\end{array}$ & Key findings & Limitations/notes/conclusion \\
\hline & & & $\begin{array}{l}\text { - Inverse relationships between } \\
\text { hypertension risk and CD4 count } \\
\text { nadir. Data suggest that } \\
\text { immunosuppression and/or viral } \\
\text { burden play a role in promoting } \\
\text { early vascular damage as } \\
\text { evidenced by the association of a } \\
\text { low CD4 cell count with } \\
\text { subclinical atherosclerotic damage, } \\
\text { a processor of hypertension }\end{array}$ & $\begin{array}{l}\text { may reflect a "return to } \\
\text { health" as individuals gain } \\
\text { weight during ART, } \\
\text { particularly with advanced } \\
\text { pre-ART disease stages } \\
\text { Limitation: smoking status and } \\
\text { laboratory results of blood } \\
\text { glucose, serum creatinine, } \\
\text { serum electrolytes, and serum } \\
\text { lipids were not available for } \\
\text { most patients; therefore, the } \\
\text { contribution of clinical factors } \\
\text { known to be associated with } \\
\text { hypertension such as diabetes } \\
\text { mellitus, chronic kidney } \\
\text { disease, and hyperlipidemia } \\
\text { could not be assessed }\end{array}$ \\
\hline
\end{tabular}

Dimala et al. 2016 Cross-sectional study conducted 200

[33]

in Cameroon among PLWH

$\mathrm{HIV}+\mathrm{ART}$ and

Feigl et al. 2016 [34] Prospective study from South Africa among PLWH

$\begin{array}{cr}\text { Kalyesubula et al. } & \begin{array}{r}\text { Retrospective study from } \\ \text { Uganda among PLWH }\end{array}\end{array}$

Kwarisiima et al 2016 [36] ART-naive participants
505 participants: HIV+ on ART, ART-naive $\mathrm{HIV}+$ and HIV-negative controls

$1996 \mathrm{HIV}+$ on

ART and

ART-naive participants
- Prevalence of HTN in patients on HAART was twice $(38 \%$; $95 \%$ CI 28.5-48.3) that of the

HAART-naive patients (19\%; $95 \%$

CI, 11.8-28.1), $p=0.003$

- $\mathrm{CD} 4$ cell count (mean $\pm \mathrm{SD}$, cells $/ \mu \mathrm{L}$ ) of ART $501 \pm 225$ was higher than the ART naive $197 \pm 160<0.001$

- HTN was associated with older age and male gender, in the HAART group

- DBP increased in ART naive but SBP reduced compared to the HIV-negative group

- SBP in the HIV+ on ART- group showed a significant decline

- Prevalence of hypertension was $20.9 \%$ (418/1996) rising from $16.9 \%$ in 2009 to $32.3 \%$ in 2013

- Patients > 50 years of age had 3.12 times the odds of hypertension compared with patients aged 20-29 years (95\% CI 2.00 to 4.85 )

- Men had 1.65 times the odds of hypertension compared with women (95\% CI 1.34 to 2.03 ) and patients with a BMI of $35-39 \mathrm{~kg} / \mathrm{m}^{2}$ had 3.93 times the odds of hypertension compared with patients with a BMI $<25 \mathrm{~kg} / \mathrm{m}^{2}$

- Patients with a WHO disease staging of 3 or 4 had 0.60 times the odds of hypertension compared with patients with stage 1 or 2 (95\% CI 0.46 to 0.76 )

- Hypertension prevalence was $11 \%$ among HIV-positive individuals participants HIV+ and HIV negative
- $79 \%$ of patients were previously undiagnosed, $85 \%$ were not taking medication, and $50 \%$ of patients on
Immune mechanism or inflammation as it relates to hypertension was not addressed

They could not control for a range of potential time-variant confounders in their analysis due to lack of data

Analysis did not distinguish ART and ART-naive patients as this can confound results
Immune mechanism or inflammation as it relates to hypertension was not explicitly addressed 
Table 3 (continued)

Author/ Type of study, country and population
Sample size and Key findings subjects

Njelekela et al. 2016 Cross-sectional study from [37]

Osegbe et al. 2016 [38]

Malawi

34,111

HIV-positive ART naive only

283

HIV+ on ART, ART naive and HIV-negative participants medication had uncontrolled blood pressure

- Multivariate predictors of hypertension included older age, male gender, higher BMI, lack of education, alcohol use, and residence in Eastern Uganda

- HIV-negative status was independently associated with higher odds of hypertension (OR $1.2,95 \%$ CI 1.1-1.4).

Viral suppression of HIV did not significantly predict hypertension among HIV positives

- The prevalence of HTN was greater among HIV-negative adults (14\%) than among HIV-positive adults $(11 \%)$

- Among HIV-positive adults with HTN, 20\% reported prior knowledge of HTN, and 14\% reported taking medication

- Similar to the overall population, $46 \%$ of HIV-positive adults with HTN achieved BP control with antihypertensive medications

- Prevalence of hypertension was found to be $12.5 \%$

- Risk of hypertension was $10 \%$ more in male than female patients

- Patients aged $\geq 50$ years had more than 2-fold increased risk for hypertension compared to 30-39-year-old patients

- Overweight and obesity were associated with $51 \%$ and $94 \%$ increased risk for hypertension compared to normal weight patients

- Low $\mathrm{CD}^{+} \mathrm{T}$ cell count, advanced WHO clinical disease stage, and history of TB were associated with $10 \%, 42 \%$, and $14 \%$ decreased risk for hypertension

- SBP in HIV+ ART was higher $(124.9 \pm 20.7 \mathrm{mmHg})$ compared to $\mathrm{HIV}+\mathrm{ART}$ naive which was higher than $(121.5 \pm 20.7) \mathrm{HIV}$ negative $(114.8 \pm 11.7 p=0.001)$

- hsCRP = 2.9 (1.4-11.6), $p=0.002$ were higher among the HIV-naive subjects

- Higher prevalences of the risk factors were noted among the HIV-treated subjects except low HDL-C $(p<0.001)$ and hsCRP $(p=0.03)$ which were higher in the HIV-naive group

- Prevalence was $23.7 \%$ (95\%-confidence interval
Limitations/notes/conclusion
Immune suppression and history of TB were associated with lower risk for hypertension
Immune mechanism or inflammation as it relates to hypertension was not addressed; however, hsCRP was higher among ART-naive patients
Immune mechanism or inflammation as it relates to


Table 3 (continued)

\begin{tabular}{|c|c|c|c|}
\hline Author/ & $\begin{array}{l}\text { Type of study, country and } \\
\text { population }\end{array}$ & $\begin{array}{l}\text { Sample size and } \\
\text { subjects }\end{array}$ & Key findings \\
\hline & & $\begin{array}{l}\mathrm{HIV}+(95 \% \text { were } \\
\text { on ART and } 5 \% \\
\text { ART naive })\end{array}$ & $\begin{array}{l}\text { 21.1-26.6; rural } 21.0 \% \text { vs. urban } \\
26.5 \% ; p=0.047 \text { ) } \\
\text { - Hypertension diagnosis was } \\
\text { associated with increasing age, } \\
\text { higher body mass index, presence } \\
\text { of proteinuria, being on regimen } \\
\text { zidovudine/lamivudine/nevirapine } \\
\text { and inversely with World Health } \\
\text { Organization clinical stage at ART } \\
\text { initiation }\end{array}$ \\
\hline Magodoro et al. 2016 & Cross-section study conducted & 1033 participants & - Hypertension prevalence was $10.2 \%$ \\
\hline
\end{tabular}

\section{Kazooba et al. 2017 Cross-section study from [43] Uganda}

Mayanja et al. 2017 Prospective study from Uganda [44]
Prospective study from Nigeria

Prospective study conducted in Lusaka, Zambia among PLWH

896 cohort HIV+ on ART participants

\section{3 participants- 229 on ART and 74 ART naive}

In this propensity score-matched sample, the estimated average treatment effects on the treated (ATT) for the effects of antiretroviral therapy on systolic (7.85 $\mathrm{mmHg}, 95 \%$ CI 3.72 to 15.68) and diastolic blood pressure (7.45 $\mathrm{mmHg}, 95 \%$ CI 4.99 to $13.61)$ were statistically significant $(p<0.001$ for each)

- 98 (10.9\%) had HBP, and 57 (6.4\%) had HTN

- Increasing age (10-year increase in age: adjusted odds ratio $[\mathrm{AOR}]=1.50 ; 95 \%$ confidence interval [CI] 1.20-1.93), male sex $(\mathrm{AOR}=2.33,95 \%$ CI $1.43-3.80)$, and overweight/obesity $(\mathrm{AOR}=4.07 ; 95 \%$ CI $1.94-8.53)$ were associated with HBP

- Among 66 patients with HBP, 35 $(53.0 \%)$ reported awareness of the condition

- Pre-ART CD4 ${ }^{+}$count was not associated with HBP

HBP tends to become more common after ART initiation and may cause HTN

$1024 \mathrm{HIV}+\mathrm{ART} \quad \cdot$ Hypertension prevalence was $22.6 \%$

- Protease inhibitor (PI) containing regimens were significantly associated with, hypertension

- Men had significantly higher mean SBP $(p=0.004)$

- Increasing age was significantly associated with higher means of SBP, DBP

- Increasing intensity of physical activity was significantly associated with lower; SBP, DBP

- Patients on non-PI regimens had higher mean diastolic hypertension than patients on PI regimens, $p<0.001$
Limitations/notes/conclusion

hypertension was not addressed

Studies had other substantial burden of comorbid non-communicable diseases among HIV-infected patients in a high HIV and low-income setting

There is a high probability that the epidemiological association between antiretroviral therapy and increased blood pressure be causal in nature among people living with HIV in Sub-Saharan African settings

Coinfection with HBV,

HBP was defined as a single elevated measurement, and $\mathrm{BP}$ was measured only once at each time point. This may have inflated the number of patients truly needing treatment, as only $58 \%$ of patients with HBP were confirmed to have HTN

These data demonstrate that although integration of BP screening and management in HIV care settings was feasible in Zambia, virtually no patient had optimal management of HBP

Immune mechanism or inflammation as it relates to hypertension was not addressed

Immune mechanism or inflammation as it relates to hypertension was not addressed 
Table 3 (continued)

$\begin{array}{ll}\text { Author/ } & \begin{array}{l}\text { Type of study, country and } \\ \text { population }\end{array}\end{array}$

Okpa et al. 2017 [45] Cross-section study from Nigeria

\section{Sample size and} subjects
Key findings

- Prevalence of hypertension was $14.5 \%$

$112 \mathrm{HIV}+$ and $309 \cdot$ The prevalence of HTN was $19.5 \%$ HIV-negative participants among HIV-infected persons

- The prevalence of pre-HTN in
RodrõÂguez-Arbolõ Prospective study from Tanzania 955 HIV+ et al. 2017 [46] HIV-positive and HIV-negative participants was $34.5 \%$ and $38.9 \%$, respectively

- The higher prevalence of HTN in HIV patients has been shown to be associated with the use of ART

- In our study, the risk factors that were associated with HTN in HIV-infected patients and the HIV-N controls were older age, increased weight and BMI, and presence of obesity. Male sex was associated with HTN in the HIV-infected population, but this was, however, not so in the general population

- Male sex and duration of exposure to ART and CD4 count levels $>200$ cells $/ \mathrm{mm}^{3}$ were associated with HTN in HIV-infected patients, whereas the absence of family history of HTN was significantly associated with HTN in both groups

- The mean age, weight, and BMI were significantly higher in HIV patients with HTN as compared to those without HTN, $p<0.05$

- A proportion of HIV patients with a family history of HTN and obesity had HTN, and these were statistically significant $(p<0.05)$

- Also, the mean waist-hip ratio, duration of illness, exposure to ART, and CD4 count levels were higher in HIV patients with HTN as compared to those without HTN, but these were not statistically significant

- $111(11.6 \%)$ were hypertensive at recruitment

- 80 (9.6\%) of them developed hypertension during a median follow-up of 144 days from time of enrolment into the cohort [incidence rate 120.0 cases/ 1000 person-years, $95 \%$ confidence interval (CI) $97.2 \pm 150.0]$

Isa et al. 2017 [47]
Prospective study from Nigeria/ Follow-up from initiating HIV+ ART and naive
- Prevalence of hypertension at enrolment was $19.3 \%$ (95\% CI 17.6-20.9\%)

- Age $(p<0.001)$, male sex $(p=0.004)$, and body mass index (BMI) $(p<0.001)$ were
Limitations/notes/conclusion

Diet and sodium intake of the participants and renal function of the participants which have been shown in several studies to have effect on BP were not looked at in our study

Immune mechanism or inflammation as it relates to hypertension was not addressed
Traditional cardiovascular risk factors predicted incident hypertension, but no association was observed with immunological or ART status. These data support the implementation of routine hypertension screening and integrated management into HIV programs in rural Sub-Saharan Africa

Hypertension is common in HIV-infected individuals attending the HIV clinic. Patients initiating ART have a high risk of developing 
Table 3 (continued)

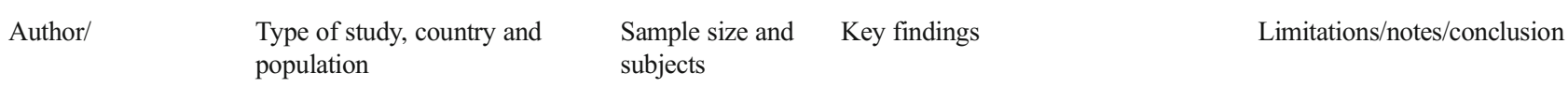

Magande et al. 2016 Case control study from [48] Zimbabwe among HIV+ on ART

Chepchirchir et al. $2018[13 \cdot \bullet]$

Okello et al. 2017

Mukeba-Tshialala et al. 2017 [50]

Cross-section study from Kenya among HIV+

\footnotetext{
Cross-section study from the Republic of Congo
}

$300(152$ controlled HTN, 152 uncontrolled HTN) independent risk factors for hypertension

- 12 months after initiating ART, a further 31\% (95\% CI 17.6-20.9\%) had developed hypertension. Total prevalence at that point was $50.2 \%$

- Hypertension among those on ART was associated with age $(p=0.009)$ and BMI $(p=0.008)$, but not with sex

- There were no independently significant associations between hypertension and $\mathrm{CD} 4^{+}$counts, viral load, or type of ART

- Adding salt to dishes regularly AOR = 5.69 (3.19-10.16), body mass index (BMI) above $25 \mathrm{~kg} / \mathrm{m}^{2}$ $\mathrm{AOR}=2.81(1.60-4.91)$ and history of elevated blood pressure in previous year $\mathrm{AOR}=2.34$ (1.33-4.13) were independent risk factors for uncontrolled hypertension

- Independent protective factors were duration more than 2 years since $\mathrm{HIV}$ diagnosis $\mathrm{AOR}=0.58$ (0.35-0.95), duration less than 5 years since hypertension diagnosis $\mathrm{aOR}=0.50(0.30-0.83)$ and walking or cycling as a means of transport $\mathrm{AOR}=0.27$ (0.16-0.48)

The prevalence of hypertension was found to be $23.2 \%$
577 HIV-infected and 538 matched HIV-uninfected participants
592

HIV-uninfected and 445 HIV-infected patients
- HIV infection was associated with $3.3 \mathrm{mmHg}$ lower systolic BP $(1.2-5.3 \mathrm{mmHg}), 1.5 \mathrm{mmHg}$ lower diastolic BP (0.2-2.9 $\mathrm{mmHg}), 0.3 \mathrm{~m} / \mathrm{s}$ lower pulse wave velocity (0.1-0.4 $\mathrm{mmHg}$ ), and $30 \%$ lower odds of hypertension $(10 \%-50 \%)$

- Body mass index mediated $25 \%$ of the association between HIV and systolic BP

- $11.5 \%$ of HIV-infected patients had an average blood pressure suggesting hypertension versus $10.6 \%$ of HIV uninfected $(p=0.751)$

- But in absolute value, HIV-infected patients had a median of diastolic hypertension in the first year of ART

Salt HTN interaction attributed to water retention resulting in high intravascular volumes. Immune mechanism or inflammation as it relates to hypertension was not addressed

Hypertension is a highly prevalent comorbidity in HIV patients. The risk factors include prolonged use of ART as well as increased body mass index. The effects of hypertension on HIV progression include low $\mathrm{CD} 4^{+}$ $\mathrm{T}$ cell counts which complicate the underlying immunosuppression

HIV infection was inversely associated with systolic BP, diastolic BP, and pulse wave velocity

Immune mechanism or inflammation as it relates to hypertension was not addressed

Immune mechanism or inflammation as it relates to hypertension was not addressed 
Table 3 (continued)

\begin{tabular}{|c|c|c|c|c|}
\hline Author/ & $\begin{array}{l}\text { Type of study, country and } \\
\text { population }\end{array}$ & $\begin{array}{l}\text { Sample size and } \\
\text { subjects }\end{array}$ & Key findings & Limitations/notes/conclusion \\
\hline $\begin{array}{r}\text { Mathabire Rücker } \\
\text { et al. } 2018 \text { [51] }\end{array}$ & $\begin{array}{l}\text { Cross-section from Malawi } \\
\text { among PLWH }\end{array}$ & $\begin{array}{l}379 \text { HIV-infected } \\
\text { patients on ART } \\
\text { and } 356 \\
\text { controls } \\
\text { participated }\end{array}$ & $\begin{array}{l}\text { blood pressure of } 90 \mathrm{mmHg} \text { versus } \\
85 \mathrm{mmHg} \text { of HIV uninfected } \\
(p<0.001) \\
\text { - Among HIV patients, the prevalence } \\
\text { of hypertension was } 19.5 \%(95 \% \\
\text { CI 15.6-23.6), of which } 60.3 \% \\
(n=44) \text { was previously } \\
\text { undiagnosed } \\
\text { - Among controls, } 25.8 \% \text { ( } 95 \% \text { CI } \\
21.6-30.7) \text { prevalence of HTN and } \\
37.0 \% \text { of controls with elevated } \\
\text { blood pressure }\end{array}$ & $\begin{array}{l}\text { Immune mechanism or } \\
\text { inflammation as it relates to } \\
\text { hypertension was not } \\
\text { addressed }\end{array}$ \\
\hline
\end{tabular}

DBP, diastolic blood pressure; SBP, systolic blood pressure; PLWH, people living with HIV; HTN, hypertension; HIV, human immunodeficiency virus; BP, blood pressure; ART, antiretroviral therapy; PI, protease inhibitors; BMI, body mass index; CI, confidence interval; cART, combinational ART; TDF, Tenofovir; AZT, Zidovudine; NVP, Nevirapine; EFV, Efavirenz; HAART, highly active antiretroviral therapy; LPV/r, lopinavir/ritonavir; TC, total cholesterol; HDL-c, high-density lipoprotein cholesterol

contradictory finding is likely due to differential effects of specific ART regimens and other traditional risk factors differing between study populations. The effect of specific regimens on blood pressure has not yet been well established except for the low to moderate increase attributed to nonnucleoside reverse transcriptase inhibitors (NNRTI's) and protease inhibitors (PIs) [59, 60]. Prior studies have shown that patients become hypertensive in most cases at least after 2 years of ART and systolic pressure increases further after 5 years of ART [60], and that there is no association between HIV status, ART, and hypertension following short-term follow-up of less than 2 years $[22,61]$.

\section{Markers of Immune Activation or Inflammation Associated with Hypertension in HIV}

Traditional risk factors associated with hypertension in HIV such as older age, male gender, African-American, higher $\mathrm{BMI}$, central obesity, previous $\mathrm{CV}$ events, chronic kidney disease, family history of hypertension and CVD, diabetes, and dyslipidemia have been well studied [57••, 58]. It is also well established that HIV infection and exposure to ART (more than 2 years), through metabolic disturbances and endothelial dysfunction, might have an additional role in the development of hypertension in HIV patients [57 ••, 58]. However, little is known about the contribution of the innate and adaptive immune system in the development or propagation of hypertension in HIV.

In our systematic review, we found that an improved immune status as determined by higher CD4 T cells was associated with higher hypertension prevalence [17]. However, one study be Okello et al. found that CD4 T cell count of less than 100 was associated with incident hypertension [61]. Martin-Iguacel et al. and Nguyen et al. also reported similar findings $[57 \bullet \bullet, 58]$. We found that $\mathrm{T}$ cell-derived cytokines IL-17A and IFN- $\gamma$ were associated with hypertension in ART treated PLWH as reported by Chepchirchir et al. $[13 \bullet \cdot]$. These cytokines have been reported to contribute to the genesis of hypertension in the HIV-negative general population and experimental animal studies [6]. Further studies are needed to ascertain the contribution of CD4 T cells and their cytokines IL-17 and IFN- $\gamma$ in concert with existing traditional risk factors on blood pressure elevation in HIV.

\section{Immune Activation, Inflammation, and Hypertension}

The role of innate and adaptive immunity including specific cell types and cytokines in the development and maintenance of hypertension has been extensively studied in humans and animal models elsewhere $[6,7,62 \bullet, 63-65]$. Using multiple experimental animal models, studies have shown that hypertensive stimuli including angiotensin II, aldosterone, endothelin-1, and salt induce activation of immune cells, which infiltrate the vasculature and the kidneys, and release cytokines that induce increased salt and water retention leading to hypertension [6]. This process is mediated in part by increases oxidative stress leading to oxidation of fatty acids and formation of isolevuglandins (IsoLGs) in antigenpresenting cells. IsoLGs activate these cells to produce proinflammatory cytokines IL-6, IL- $1 \beta$, and IL-23, express costimulatory proteins CD80 and CD86, and activate T cells to produce pro-hypertensive cytokines IFN- $\gamma$ and IL-17A [7]. In humans, plasma isoprostanes, which are produced in concert with IsoLGs, are elevated in hypertension and markedly elevated in patients with resistant hypertension, and IsoLGs are markedly elevated in circulating monocytes of hypertensive patients [7]. IL-17A and IFN- $\gamma$ have been implicated in the genesis and maintenance of hypertension due in part to 
Table 4 Studies on HIV and immune activation/inflammation

\begin{tabular}{|c|c|c|c|c|}
\hline Author/ & $\begin{array}{l}\text { Type of study/populations/country/ } \\
\text { study period }\end{array}$ & Sample size/methods & Key findings & Limitations/notes \\
\hline $\begin{array}{l}\text { Fourie } \\
\text { et al. } \\
2011 \\
{[52]}\end{array}$ & $\begin{array}{l}\text { Sub-study nested in the larger } \\
\text { longitudinal, multinational PURE } \\
\text { study in South Africa among } \\
\text { PLWH/HIV+ and HIV- }\end{array}$ & $\begin{array}{l}600 \text { HIV+ and } \\
\text { HIV-negative } \\
\text { controls }\end{array}$ & $\begin{array}{l}\text { - HIV+ showed higher IL-6, CRP, ICAM-1, } \\
\text { and VCAM-1 levels compared to HIV } \\
\text { negative } \\
\text { - Accelerated vascular aging and probable } \\
\text { early atherosclerosis in the older } \\
\text { HIV-infected participants } \\
\text { - HIV-1 Tat protein (therefore HIV itself) } \\
\text { induced the expression of ICAM-1 and } \\
\text { VCAM-1 }\end{array}$ & $\begin{array}{l}\text { Immune mechanism or } \\
\text { inflammation as it relates to } \\
\text { hypertension was not } \\
\text { addressed }\end{array}$ \\
\hline $\begin{array}{l}\text { Cassol } \\
\text { et al. } \\
2010 \\
{[53]}\end{array}$ & $\begin{array}{l}\text { Cross-section study conducted from } \\
\text { South Africa }\end{array}$ & $\begin{array}{l}90 \text { participants } \\
10 \text { HIV-negative } \\
\text { controls, } 20 \mathrm{HIV+} \\
\text { on ART, and } 60 \\
\text { ART-naive HIV+ }\end{array}$ & $\begin{array}{l}\text { - } \mathrm{CD} 14^{+} 16^{+} \text {positively correlated with HIV-1 } \\
\text { viremia } \\
\text { - IL- } 6 \text { increased in presence of OPIs } \\
\text { - } \mathrm{sCD} 14 \text { and TNF correlated with plasma LPS } \\
\text { levels and remained elevated in ART } \\
\text { - Microbial translocation is a major force } \\
\text { driving chronic inflammation in } \\
\text { HIV-infected Africans receiving cART }\end{array}$ & $\begin{array}{l}\text { All participants were } \\
\text { immunocompromised with } \\
\text { CD4 counts of } \\
<200 \text { cells/ } \mu \mathrm{L} \\
\text { Immune mechanism or } \\
\text { inflammation as it relates to } \\
\text { hypertension was not } \\
\text { addressed } \\
\text { Prevention of monocyte } \\
\text { activation may be } \\
\text { especially effective at } \\
\text { enhancing therapeutic } \\
\text { outcomes }\end{array}$ \\
\hline $\begin{array}{l}\text { Fourie } \\
\text { et al. } \\
2011 \\
{[52]}\end{array}$ & $\begin{array}{l}\text { Cross-section study from South } \\
\text { Africa }\end{array}$ & $\begin{array}{l}300 \text { ART-naive HIV+ } \\
\text { vs } 300 \text { HIV } \\
\text { negative }\end{array}$ & $\begin{array}{l}\text { - Suggestion of inflammatory injury of the } \\
\text { endothelium } \\
\text { - Indication of accelerated vascular aging and } \\
\text { probable early atherosclerosis in the older } \\
\text { HIV-infected participants }\end{array}$ & $\begin{array}{l}\text { Contribution of innate and } \\
\text { adaptive immune system } \\
\text { were not included or } \\
\text { addressed }\end{array}$ \\
\hline $\begin{array}{l}\text { Canipe } \\
\text { et al. } \\
2014 \\
{[54]}\end{array}$ & $\begin{array}{l}\text { Zambia/pilot study } 12 \text { months } \\
\text { prospective }\end{array}$ & $\begin{array}{l}33 \text { HIV+ on ART for } \\
12 \text { months }\end{array}$ & $\begin{array}{l}\text { - Biomarkers of increased microbial } \\
\text { translocation (lipopolysaccharide binding } \\
\text { protein, endotoxin core IgG and IgM, and } \\
\text { soluble CD14) were associated with high } \\
\text { levels of systemic inflammation before and } \\
\text { after initiation of ART, suggesting that } \\
\text { impaired gut immune defenses contribute to } \\
\text { innate immune activation in this population }\end{array}$ & $\begin{array}{l}\text { All the HIV-infected adults in } \\
\text { the study were } \\
\text { undernourished }\end{array}$ \\
\hline $\begin{array}{l}\text { Siedner } \\
\text { et al. } \\
2016 \\
{[55]}\end{array}$ & Prospective study from Uganda & $\begin{array}{l}105 \text { HIV positive } \\
\text { initiating ART }\end{array}$ & $\begin{array}{l}\text { - Persistent immune activation (sCD14 level } \\
\text { and kynurenine-tryptophan ratio) and } \\
\text { inflammation (IL-6) despite ART-mediated } \\
\text { viral suppression predicted future } \\
\text { atherosclerotic burden among HIV-infected } \\
\text { Ugandans }\end{array}$ & $\begin{array}{l}\text { Immune mechanism or } \\
\text { inflammation as it relates to } \\
\text { hypertension was not } \\
\text { addressed }\end{array}$ \\
\hline
\end{tabular}

PLWH, people living with HIV; HIV, human immunodeficiency virus; CRP, C-reactive protein; ART, antiretroviral therapy; IL, interleukin; TNF $\alpha$, tumor necrosis factor alpha; cART, combinational ART; sCD14, soluble CD14; sCD163, soluble CD163; VCAM-1, vascular cell adhesion molecule 1; ICAM-1, intercellular adhesion molecule 1

their direct effect in causing endothelial dysfunction and renal damage $[6,66]$. Thus, similar immuno-pathophysiological mechanisms underlying hypertension in the general population may also contribute to elevated blood pressure in PLWH.

\section{Potential Mechanisms Leading to Inflammation in HIV}

The pathophysiology of HIV-related hypertension seems to emerge from three factors: HIV-related inflammation, HIVrelated proteins, and genetic predisposition [59]. It is believed that the HIV viral proteins (negative factor (Nef), transcription proteins (Tat) and glycoprotein 120 (gp-120)) induce hypertension through vascular oxidative stress, smooth myocyte proliferation and migration, and endothelial dysfunction especially in patients with high HIV viral load [59]. Tat, a transactivator protein for HIV replication, is known to be secreted extracellularly by infected cells and has been shown to activate endothelial cells by increasing expression of endothelial-leukocyte adhesion molecules such as intercellular adhesion molecule-1 (ICAM-1), vascular cell adhesion molecule-1 (VCAM-1), and E-selectin which induce initial binding of leukocytes to the blood vessel wall [67]. The levels of soluble ICAM-1 concentration correlate with HIV 
Fig. 1 Conceptual schematic of the effect of HIV infection and treatment can activate the immune system leading to hypertension. Viral proteins and/or antiretroviral therapy (ART) activates antigen presenting and $\mathrm{T}$ cells which infiltrate the vasculature and the kidneys and release cytokines IL6 , IL-17A, and IFN- $\gamma$ which promote vascular dysfunction, retention of sodium, and water, leading to hypertension

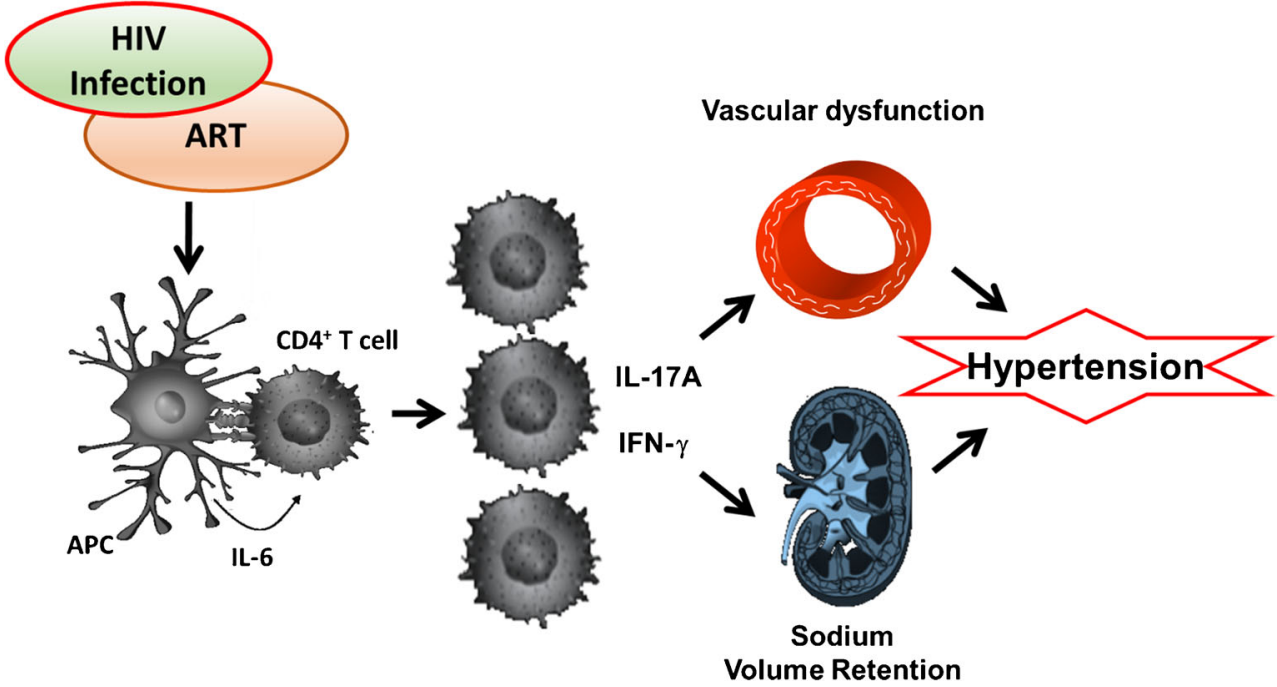

disease as well as reduction in CD4 count. Tat also induces IL-6 production which increases endothelial permeability [67]. Tat can also suppress the bone morphogenic protein receptor 2 (BMPR-2) responsible for regulating endothelial cell proliferation and survival. This results in increased vascular smooth muscle proliferation and activation of endothelial cells leading to pulmonary arterial hypertension (PAH) [68]. In HIV-positive patients, Tat has been shown to increase the transcription of IL-17 and secretion by $\mathrm{T}$ cells causing a pro-inflammatory milieu and has been associated with a devastating immune reconstitution inflammatory syndrome (IRIS) in the brain [69]. The HIV Gp120 is found on the surface of the HIV envelope and can also be found in circulation from viral turn over [70]. Gp120 stimulates monocytes and macrophages to release pro-inflammatory cytokines, promotes an increase in markers of apoptosis, and stimulates the secretion of endothelin-1, a potent vasoconstrictor [68]. It induces endothelial apoptosis by interacting with CXCR4 also expressed on endothelial cells [70]. Gp120 and TNF- $\alpha$ synergistically decrease eNOS and NO in human coronary artery endothelial cells [70].

DCs, the most potent antigen-presenting cells of the innate immune system, have been shown to interact with components of HIV-1 both intrinsically (following fusion of cellular and viral membrane) and extrinsically (prior to being infected) through pathogen recognition receptors (PRRs) resulting in activation of the adaptive immune system [71]. Through their CD28/B7 ligands CD80 and CD86 (also expressed on monocytes and B cells), DCs provide a costimulatory signal necessary for T cell activation and survival. In hypertension, there is an increase in B7 ligand expression leading to T cell activation $[5,72]$. An important element in the activation of T cells by DCs and other cells in hypertension is antigen presentation. It is unclear what antigens are presented to T cells in HIV and it is not known if IsoLG-adducted peptides might play a role in hypertension associated with HIV.
Monocyte activation has an important role in HIV-infected persons on ART. Monocytes are chronically activated during HIV infection and it is now evident that inflammatory mediators produced by monocytes (especially IL-6), independent of $\mathrm{T}$ cell activation, also predict serious non-AIDS events (SNAEs) in virologically suppressed HIV-infected persons treated with ART [73]. IL-6 production was higher in monocytes than other cells and was associated with increased odds of SNAE and mortality but not the percentage of activated CD4 and CD8 T cells (those expressing CD38 or CD38 and HLA-DR) [73]. Infected monocytes, especially intermediate monocytes expressing $\mathrm{CD} 14^{+}$and $\mathrm{CD} 16^{+}$, produce more proinflammatory cytokines as compared to their counterpart. They adhere to endothelial cells and transmigrate into the sub endothelial area where their pro-inflammatory activity is increased. It is evident that in HIV, monocytes and macrophages have a reduced phagocytic activity and they age prematurely [70]. Monocytes/macrophages have been implicated in the pathogenesis of hypertension in the general population and experimental animal models [5].

Several mechanisms of immune cell activation have been reported in HIV. First, there is direct binding of the HIV envelope protein gp120/160 to CD4 and/or C-C chemokine receptor type 5 (CCR5) which down-modulates the expression of $\mathrm{CD}^{+}{ }^{+}$cell receptor in infected cells resulting in cell death; second, there is an interaction between HIV viral particles and plasmacytoid dendritic cells (DCs) through Toll like receptor (TLR) stimulation which activates $\mathrm{CD}^{+}$cytotoxic cells; third, there is microbial translocation from a leaky gut into the circulation leading to a generalized systemic inflammatory process [74]. Also important is the dysfunction of $\mathrm{T}$ regulatory cells and immune-senescence resulting in an uncontrolled over activation of immune cells in HIV [74]. The resultant low-grade chronic inflammation which persists even after initiation of ART is associated with hypertension and cardiovascular disease [75, 76]. 
IL-6 production by monocytes and macrophages is increased following HIV infection and is a valuable prognostic marker for disease progression [77, 78]. Soluble CD14 (sCD14) produced from monocytes and macrophages is also elevated in HIV-infected persons regardless of treatment status and is an independent predictor of mortality [73]. Anzinger et al. reported that increased microbial translocation from the gut resulting from depletion of $\mathrm{CD}^{+} \mathrm{T}$ cells in acute HIV infection results in monocyte activation and higher $\mathrm{SCD} 14$ [73]. The expression of programmed death-1 (PD-1), a member of the B7:28 inhibitory molecules, is rapidly increased on $\mathrm{CD}^{+}{ }^{+}$and $\mathrm{CD} 8^{+} \mathrm{T}$ cells, B cells, natural killer cells, and monocytes as they interact with PD-L1, its ligand on antigenpresenting cells such that engagement on virus-infected cells leads to impaired generation of effector $\mathrm{T}$ cell responses [74]. Other markers which have been associated with immune activation in HIV include increased expression of CD28 $\mathrm{CD} 57^{+}$and reduced expression of $\mathrm{CD} 127$ on $\mathrm{CD} 4^{+}$and $\mathrm{CD}^{+} \mathrm{T}$ cells $[79,80]$.

In our analysis, we found HIV infection alone is associated with an inflammatory milieu involving higher levels of IL-6, CRP, VCAM-1 ICAM-1, and intermediate monocytes $\left(\mathrm{CD} 14^{+} 16^{+}\right)$among studies conducted in Sub-Saharan African cohorts $[17,55]$. There is a generalized systemic immune activation following HIV infection which subsides but still persists at low-grade or subclinical following initiation of ART involving activation of both $\mathrm{CD}^{+}$and $\mathrm{CD} 8^{+} \mathrm{T}$ cells expressing high levels of CD38 [74]. Other T cell activation markers such as human leukocyte antigen-antigen D related (HLA-DR) as well as increases in pro-inflammatory cytokines tumor necrosis factor alpha (TNF- $\alpha$ ), interleukin 6 (IL-6), and interleukin 1 beta (IL-1 $\beta$ ) have been reported in PLWH in the western countries [74]. Increased expression of CD38 alone or in concert with HLA-DR ${ }^{+}$in T cells is a marker of disease progression and mortality in some cases correlating directly with HIV viral load and indirectly with $\mathrm{CD}^{+}$count [74]. This continuous immune activation and inflammation has been proposed to contribute to endothelial dysfunction, hypertension, and cardiovascular disease [81].

\section{Limitations, Conclusion, and Future Perspectives}

Almost all studies except one [13••] were not designed to compare blood pressure or hypertension and inflammation in PLWH as the primary outcomes. There is need for additional prospective and mechanistic studies to establish the relationship between inflammation and hypertension in HIV infection, and ART. Most studies addressing the mechanistic role of inflammation in the genesis and progression of hypertension have been conducted in murine models and humans in the HIV-negative context. The inflammatory milieu in HIV infection is obviously complex and very different from the general population and further studies are needed to determine the specific contribution of the various attributes in HIV including the viral proteins and ART on inducing inflammation associated with hypertension.

Acknowledgments Graphics were produced using the online ePath3D toll (Protein Lounge, Inc.).

Authors' Contributions SKM and AK conceived the study. SKM, AK conducted the data collection. SKM, BMH, SN, DH, JRK, GK, WM, $\mathrm{SM}$, and AK conducted article reviews and led the writing of the manuscript. All authors read, provided feedback, and approved the final manuscript.

Funding This work was supported by the Fogarty International Center of the National Institutes of Health under the Award Number D43 TW009744, NIAID Grant K23 AI100700, the NIH-funded Vanderbilt Clinical and Translational Science award from NCRR/NIH Grant UL1 RR024975, the NIH-funded Tennessee Center for AIDS Research Grant P30 AI110527, and National Institutes of Health grant K01HL130497. This work was also supported by NIAID grant K23 100700, the NIHfunded Vanderbilt Clinical and Translational Science award from NCRR/NIH grant UL1 RR024975, and the NIH-funded Tennessee Center for AIDS Research grant P30 AI110527. The funders had no role in study design, data collection and analysis, decision to publish, or preparation of the manuscript.

\section{Compliance with Ethical Standards}

Conflict of Interest The authors declare no conflicts of interest relevant to this manuscript.

Human and Animal Rights and Informed Consent This article does not contain any studies with human or animal subjects performed by any of the authors.

Open Access This article is distributed under the terms of the Creative Commons Attribution 4.0 International License (http:// creativecommons.org/licenses/by/4.0/), which permits unrestricted use, distribution, and reproduction in any medium, provided you give appropriate credit to the original author(s) and the source, provide a link to the Creative Commons license, and indicate if changes were made.

\section{References}

Papers of particular interest, published recently, have been highlighted as:

- Of importance

•• Of major importance

1. Currier JS, Taylor A, Boyd F, Dezii CM, Kawabata H, Burtcel B, et al. Coronary heart disease in HIV-infected individuals. J Acquir Immune Defic Syndr. 2003;33:506-12.

2. Triant VA, Lee H, Hadigan C, Grinspoon SK. Increased acute myocardial infarction rates and cardiovascular risk factors among patients with human immunodeficiency virus disease. J Clin Endocrinol Metab. 2007;92:2506-12.

3. Cruse B, Cysique LA, Markus R, Brew BJ. Cerebrovascular disease in HIV-infected individuals in the era of highly active antiretroviral therapy. J Neuro-Oncol. 2012;18:264-76. 
4. Freiberg MS, Chang CC, Kuller LH, Skanderson M, Lowy E, Kraemer KL, et al. HIV infection and the risk of acute myocardial infarction. JAMA Intern Med. 2013;173:614-22.

5. Mian MOR, Paradis P, Schiffrin EL. Innate immunity in hypertension. Curr Hypertens Rep. 2014;16:413.

6. McMaster WG, Kirabo A, Madhur MS, Harrison DG. Inflammation, immunity, and hypertensive end-organ damage. Circ Res. 2015;116:1022-33.

7. Kirabo A, Fontana V, de Faria AP, Loperena R, Galindo CL, Wu J, et al. DC isoketal-modified proteins activate $\mathrm{T}$ cells and promote hypertension. J Clin Invest. 2014;124:4642-56.

8. Moher D, Shamseer L, Clarke M, Ghersi D, Liberati A, Petticrew M, et al. Preferred reporting items for systematic review and metaanalysis protocols (PRISMA-P) 2015 statement. Syst Rev. 2015;4:1.

9. Shamseer L, Moher D, Clarke M, Ghersi D, Liberati A, Petticrew $\mathrm{M}$, et al. Preferred reporting items for systematic review and metaanalysis protocols (PRISMA-P) 2015: elaboration and explanation. BMJ. 2015;349:g7647.

10. van Zoest RA, van den Born BH, Reiss P. Hypertension in people living with HIV. Curr Opin HIV AIDS. 2017;12:513-22.

11. Armah KA, McGinnis K, Baker J, Gibert C, Butt AA, Bryant KJ, et al. HIV status, burden of comorbid disease, and biomarkers of inflammation, altered coagulation, and monocyte activation. Clin Infect Dis. 2012;55:126-36.

12. Manner IW, Baekken M, Oektedalen O, Os I. Hypertension and antihypertensive treatment in HIV-infected individuals. A longitudinal cohort study. Blood Press. 2012;21:311-9.

13.• Chepchirchir A, Nyagol J, Jaoko W. Cytokine expression and hypertension comorbidity in HIV/AIDS patients at Kenyatta National Hospital HIV Care Centre, Nairobi, Kenya. Int J Cardiovasc Res 2018;7:2 This recent manuscript found that IL-17 and IFN- $\gamma$ are associated with hypertension in HIV.

14.• Peck RN, Shedafa R, Kalluvya S, Downs JA, Todd J, Suthanthiran $\mathrm{M}$, et al. Hypertension, kidney disease, HIV and antiretroviral therapy among Tanzanian adults: a cross-sectional study. BMC Med. 2014;12:125 This work found that hypertension and kidney disease were associated with HIV and ART. The study also found that CD4 $\mathrm{T}$ cell counts are associated with hypertension in HIV.

15. Fourie CMT, Schutte AE, Smith W, Kruger A, van Rooyen JM. Endothelial activation and cardiometabolic profiles of treated and never-treated HIV infected Africans. Atherosclerosis. 2015;240: 154-60.

16. Okello S, Asiimwe SB, Kanyesigye M, Muyindike WR, Boum Y, Mwebesa BB, et al. D-dimer levels and traditional risk factors are associated with incident hypertension among HIV-infected individuals initiating antiretroviral therapy in Uganda. J Acquir Immune Defic Syndr. 2016;73:4:396-402

17. Borkum MS, Heckmann JM, Manning K, Dave JA, Levitt NS, Rayner BL, et al. High prevalence of "non-dipping" blood pressure and vascular stiffness in HIV-infected South Africans on antiretrovirals. PLoS One. 2017;12:9: e0185003.

18. Bloomfield GS, Hogan JW, Keter A, Sang E, Carter EJ, Velazquez EJ, et al. Hypertension and obesity as cardiovascular risk factors among HIV seropositive patients in Western Kenya. PLoS One. 2011;6:7:e22288

19. Julius H, Basu D, Ricci E, Wing J, Basu JK, Pocaterra D, et al. The burden of metabolic diseases amongst HIV positive patients on HAART attending The Johannesburg Hospital. Curr HIV Res. 2011;9:247-52.

20. Diouf A, Cournil A, Ba-Fall K, Ngom-Guèye NF, EymardDuvernay S, Ndiaye I, et al. Diabetes and hypertension among patients receiving antiretroviral treatment since 1998 in Senegal: prevalence and associated factors. Isrn Aids. 2012;2012:621565.

21. Ngatchou W, Lemogoum D, Ndobo P, Yiagnigni E, Tiogou E, Nga $\mathrm{E}$, et al. Effects of antiretroviral therapy on arterial stiffness in
Cameroonian HIV-infected patients. Blood Press Monit. 2013;18: 247-51.

22. Parikh SM, Obuku EA, Walker SA, Semeere AS, Auerbach BJ, Hakim JG, et al. Clinical differences between younger and older adults with HIV/AIDS starting antiretroviral therapy in Uganda and Zimbabwe: a secondary analysis of the DART trial. PloS One. 2013;8:e76158.

23. Ekali LG, Johnstone LK, Echouffo-Tcheugui JB, Kouanfack C, Dehayem MY, Fezeu L, et al. Fasting blood glucose and insulin sensitivity are unaffected by HAART duration in Cameroonians receiving first-line antiretroviral treatment. Diabetes Metab. 2013;39:71-7.

24. Muhammad S, Sani MU, Okeahialam BN. Cardiovascular disease risk factors among HIV-infected Nigerians receiving highly active antiretroviral therapy. Niger Med J 2013;54:185-90

25. Mateen FJ, Kanters S, Kalyesubula R, Mukasa B, Kawuma E, Kengne AP, et al. Hypertension prevalence and Framingham risk score stratification in a large HIV-positive cohort in Uganda. J Hypertens. 2013;31:1372-8 discussion 1378.

26. Botha S, Fourie CMT, van Rooyen JM, Kruger A, Schutte AE. Cardiometabolic changes in treated versus never treated HIV-infected black South Africans: the PURE study. Heart Lung Circ. 2014;23:119-26.

27. Ogunmola OJ, Oladosu OY, Olamoyegun AM. Association of hypertension and obesity with HIV and antiretroviral therapy in a rural tertiary health center in Nigeria: a cross-sectional cohort study. Vasc Health Risk Manag. 2014;10:129-37.

28. Shaffer D, Hughes MD, Sawe F, Bao Y, Moses A, Hogg E, et al. Cardiovascular disease risk factors in HIV-infected women after initiation of lopinavir/ritonavir- and nevirapine-based antiretroviral therapy in Sub-Saharan Africa: A5208 (OCTANE). J Acquir Immune Defic Syndr 1999. 2014;66:155-63.

29. Sawadogo A, Sanou S, Hema A, Kamboule BE, Kabore NF, Sore I, et al. Metabolic syndrome and cardiovascular risk patients under antiretrovirals in a day hospital at Bobo-Dioulasso (Burkina Faso). Bull Soc Pathol Exot 1990. 2014;107:151-8.

30. Kagaruki GB, Mayige MT, Ngadaya ES, Kimaro GD, Kalinga AK, Kilale AM, et al. Magnitude and risk factors of non-communicable diseases among people living with HIV in Tanzania: a cross sectional study from Mbeya and Dar es Salaam regions. BMC Public Health. 2014;14:904.

31. Abrahams Z, Dave JA, Maartens G, Levitt NS. Changes in blood pressure, glucose levels, insulin secretion and anthropometry after long term exposure to antiretroviral therapy in South African women. AIDS Res Ther. 2015;12:24.

32. Okello S, Kanyesigye M, Muyindike WR, Annex BH, Hunt PW, Haneuse $S$, et al. Incidence and predictors of hypertension in adults with HIV initiating antiretroviral therapy in southwestern Uganda. J Hypertens. 2015;33:2039-45.

33. Dimala CA, Atashili J, Mbuagbaw JC, Wilfred A, Monekosso GL. Prevalence of hypertension in HIV/AIDS patients on Highly Active Antiretroviral Therapy (HAART) compared with HAART-naïve patients at the Limbe Regional Hospital, Cameroon. PloS One. 2016;11:e0148100.

34. Feigl AB, Bloom DE, Danaei G, Pillay D, Salomon JA, Tanser F, et al. The effect of HIV and the modifying effect of Anti-Retroviral Therapy (ART) on Body Mass Index (BMI) and Blood Pressure Levels in Rural South Africa. PloS One. 2016;11:e0158264.

35. Kalyesubula R, Kayongo A, Semitala FC, Muhanguzi A, Katantazi $\mathrm{N}$, Ayers D, et al. Trends and level of control of hypertension among adults attending an ambulatory HIV clinic in Kampala, Uganda: a retrospective study. BMJ Glob Health. 2016;1:e000055.

36. Kwarisiima D, Balzer L, Heller D, Kotwani P, Chamie G, Clark T, et al. Population-based assessment of hypertension epidemiology and risk factors among HIV-Positive and General Populations in Rural Uganda. PloS One. 2016;11:e0156309. 
37. Njelekela M, Muhihi A, Aveika A, Spiegelman D, Hawkins C, Armstrong $\mathrm{C}$, et al. Prevalence of hypertension and its associated risk factors among 34,111 HAART Naïve HIV-infected adults in Dar es Salaam, Tanzania. Int J Hypertens. 2016;2016:5958382.

38. Osegbe ID, Soriyan OO, Ogbenna AA, Okpara HC, Azinge EC. Risk factors and assessment for cardiovascular disease among HIVpositive patients attending a Nigerian tertiary hospital. Pan Afr Med J. 2016;23:206.

39. Divala OH, Amberbir A, Ismail Z, Beyene T, Garone D, Pfaff C, et al. The burden of hypertension, diabetes mellitus, and cardiovascular risk factors among adult Malawians in HIV care: consequences for integrated services. BMC Public Health. 2016;16:1243.

40. Magodoro IM, Esterhuizen TM, Chivese T. A cross-sectional, facility based study of comorbid non-communicable diseases among adults living with HIV infection in Zimbabwe. BMC Res Notes. 2016;9:379.

41. Nduka CU, Stranges S, Bloomfield GS, Kimani PK, Achinge G, Malu AO, et al. A plausible causal link between antiretroviral therapy and increased blood pressure in a sub-Saharan African setting: a propensity score-matched analysis. Int J Cardiol. 2016;220:400-7.

42. Bauer S, Wa Mwanza M, Chilengi R, Holmes CB, Zyambo Z, Furrer $\mathrm{H}$, et al. Awareness and management of elevated blood pressure among human immunodeficiency virus-infected adults receiving antiretroviral therapy in urban Zambia: a call to action. Glob Health Action. 2017;10:1359923.

43. Kazooba P, Kasamba I, Mayanja BN, Lutaakome J, Namakoola I, Salome T, et al. Cardiometabolic risk among HIVPOSITIVE Ugandan adults: prevalence, predictors and effect of long-term antiretroviral therapy. Pan Afr Med J. 2017;27:40.

44. Mayanja BN, Kasamba I, Levin J, Namakoola I, Kazooba P, Were J, et al. COHORT PROFILE: The Complications of Long-Term Antiretroviral Therapy study in Uganda (CoLTART), a prospective clinical cohort. AIDS Res Ther. 2017;14:26.

45. Okpa HO, Bisong EM, Enang OE, Monjok E, Essien EJ. Predictors of hypertension in an urban HIV-infected population at the University of Calabar Teaching Hospital, Calabar, Nigeria. HIVAIDS Auckl NZ. 2017;9:19-24.

46. Rodríguez-Arbolí E, Mwamelo K, Kalinjuma AV, Furrer H, Hatz C, Tanner M, et al. Incidence and risk factors for hypertension among HIV patients in rural Tanzania - a prospective cohort study. PloS One. 2017;12:e0172089.

47. Isa SE, Kang'ombe AR, Simji GS, Shehu NY, Oche AO, Idoko JA, et al. Hypertension in treated and untreated patients with HIV: a study from 2011 to 2013 at the Jos University Teaching Hospital, Nigeria. Trans R Soc Trop Med Hyg. 2017;111:172-7.

48. Magande PN, Chirundu D, Gombe NT, Mungati M, Tshimanga M. Determinants of uncontrolled hypertension among clients on antiretroviral therapy in Kadoma City, Zimbabwe, 2016. Clin Hypertens [Internet]. 2017;23. Available from: https://www.ncbi. nlm.nih.gov/pmc/articles/PMC5496338/.

49. Okello S, Ueda P, Kanyesigye M, Byaruhanga E, Kiyimba A, Amanyire G, et al. Association between HIV and blood pressure in adults and role of body weight as a mediator: Cross-sectional study in Uganda. J Clin Hypertens Greenwich Conn. 2017;19: 1181-91.

50. Mukeba-Tshialala D, Nachega JB, Mutombo-Tshingwali M, Arendt V, Gilson G, Moutschen M. Obesity, high blood pressure, hypercholesterolaemia, and untreated diabetes in HIV-infected and HIV-uninfected adults in Mbuji-Mayi (Democratic republic of congo). Bull Soc Pathol Exot 1990. 2017;110:301-9.

51. Mathabire Rücker SC, Tayea A, Bitilinyu-Bangoh J, BermúdezAza EH, Salumu L, Quiles IA, et al. High rates of hypertension, diabetes, elevated low-density lipoprotein cholesterol, and cardiovascular disease risk factors in HIVinfected patients in Malawi. AIDS Lond Engl. 2018;32:253-60.
52. Fourie C, van Rooyen J, Pieters M, Conradie K, Hoekstra T, Schutte A. Is HIV-1 infection associated with endothelial dysfunction in a population of African ancestry in South Africa? Cardiovasc J Afr. 2011;22:134-40.

53. Cassol E, Malfeld S, Mahasha P, van der Merwe S, Cassol S, Seebregts C, et al. Persistent microbial translocation and immune activation in HIV-1-infected South Africans receiving combination antiretroviral therapy. J Infect Dis. 2010;202:723-33.

54. Canipe A, Chidumayo T, Blevins M, Bestawros M, Bala J, Kelly P, et al. A 12 week longitudinal study of microbial translocation and systemic inflammation in undernourished HIV-infected Zambians initiating antiretroviral therapy. BMC Infect Dis. 2014;14:521.

55. Siedner MJ, Kim J-H, Nakku RS, Bibangambah P, Hemphill L, Triant VA, et al. Persistent immune activation and carotid atherosclerosis in HIV-Infected Ugandans Receiving Antiretroviral Therapy. J Infect Dis. 2016;213:370-8.

56. Peck R, Mghamba J, Vanobberghen F, Kavishe B, Rugarabamu V, Smeeth L, et al. Preparedness of Tanzanian health facilities for outpatient primary care of hypertension and diabetes: a crosssectional survey. Lancet Glob Health. 2014;2:e285-92.

57.• Martin-Iguacel R, Negredo E, Peck R, Friis-Møller N. Hypertension is a key feature of the metabolic syndrome in subjects aging with HIV. Curr Hypertens Rep. 2016;18:46 This review highlighed how HIV infection contributest to metabolic syndrome and emphazised the importance of cardiovascuscular risk screaning among people aging with HIV.

58. Nguyen KA, Peer N, Mills EJ, Kengne AP. Burden, determinants, and pharmacological management of hypertension in HIV-positive patients and populations: a systematic narrative review. AIDS Rev. 2015;17:83-95.

59. Bigna JJR, Nansseu JRN, Um LN, Noumegni SRN, Simé PSD, Aminde LN, et al. Prevalence and incidence of pulmonary hypertension among HIV-infected people in Africa: a systematic review and meta-analysis. BMJ Open. 2016;6:e11921.

60. Calò LA, Caielli P, Maiolino G, Rossi G. Arterial hypertension and cardiovascular risk in HIV-infected patients. J Cardiovas Med. 2013;14:553-8.

61. Okello S, Asiimwe SB, Kanyesigye M, Muyindike WR, Boum Y, Mwebesa BB, et al. D-dimer levels and traditional risk factors are associated with incident hypertension among HIV-infected individuals initiating antiretroviral therapy in Uganda. J Acquir Immune Defic Syndr. 2016;73:4:396-402.

62. Caillon A, Schiffrin EL. Role of inflammation and immunity in hypertension: recent epidemiological, laboratory, and clinical evidence. Curr Hypertens Rep. 2016;18:21 This review comprehensively outlines the recent findings on immunity and its links to hypertension.

63. Dinh QN, Drummond GR, Sobey CG, Chrissobolis S. Roles of inflammation, oxidative stress, and vascular dysfunction in hypertension. Biomed Res Int. 2014;2014:1-11.

64. Nguyen H, Chiasson VL, Chatterjee P, Kopriva SE, Young KJ, Mitchell BM. Interleukin-17 causes rho-kinase-mediated endothelial dysfunction and hypertension. Cardiovasc Res. 2013;97:696-704.

65. Wade B, Abais-Battad JM, Mattson DL. Role of immune cells in salt-sensitive hypertension and renal injury. Curr Opin Nephrol Hypertens. 2016;25:22-7.

66. Schiffrin EL. Immune mechanisms in hypertension and vascular injury. Clin Sci (London, England: 1979). 2014;126:267-74.

67. Hofman FM, Wright AD, Dohadwala MM, Wong-Staal F, Walker SM. Exogenous tat protein activates human endothelial cells. [see comments]. Blood. 1993;82:2774-80.

68. Correale M, Palmiotti GA, Lo Storto MM, Montrone D, Foschino Barbaro MP, Di Biase M, et al. HIV-associated pulmonary arterial hypertension: from bedside to the future. Eur J Clin Investig. 2015;45:515-28. 
69. Johnson TP, Patel K, Johnson KR, Maric D, Calabresi PA, Hasbun $\mathrm{R}$, et al. Induction of IL-17 and nonclassical T-cell activation by HIV-Tat protein. Proc Natl Acad Sci U S A. 2013;110:13588-93.

70. Shahbaz S, Manicardi M, Guaraldi G, Raggi P. Cardiovascular disease in human immunodeficiency virus infected patients: a true or perceived risk? World J Cardiol. 2015;7:633-44.

71. Iwasaki A, Medzhitov R. Regulation of adaptive immunity by the innate immune system. Science (New York, NY). 2010;327:291-5.

72. Vinh A, Chen W, Blinder Y, Weiss D, Taylor WR, Goronzy JJ, et al. Inhibition and genetic ablation of the B7/CD28 T-cell costimulation axis prevents experimental hypertension. Circulation. 2010;122: 2529-37.

73. Anzinger JJ, Butterfield TR, Angelovich TA, Crowe SM, Palmer CS. Monocytes as regulators of inflammation and HIV-related comorbidities during cART. J Immunol Res. 2014;2014:1-11.

74. Mohan T, Bhatnagar S, Gupta DL, Rao DN. Current understanding of HIV-1 and T-cell adaptive immunity: progress to date. Microb Pathog. 2014;73:60-9.

75. D'Abramo A, Zingaropoli MA, Oliva A, D'Agostino C, Al Moghazi S, De Luca $G$, et al. Immune activation, immunosenescence, and osteoprotegerin as markers of endothelial dysfunction in subclinical HIV-associated atherosclerosis. Mediat Inflamm. 2014;2014:192594.
76. Tsoukas C. Immunosenescence and aging in HIV. Curr Opin HIV AIDS. 2014;9:398-404.

77. Borges ÁH, O'Connor JL, Phillips AN, Rönsholt FF, Pett S, Vjecha MJ, et al. Factors associated with plasma IL-6 levels during HIV infection. J Infect Dis. 2015;212:585-95.

78. Nixon DE, Landay AL. Biomarkers of immune dysfunction in HIV. Curr Opin HIV AIDS. 2010;5:498-503.

79. Aberg JA. Aging, inflammation, and HIV infection. Top Antivir Med. 2012;20:3:101-5

80. Mojumdar K, Vajpayee M, Chauhan NK, Singh A, Singh R, Kurapati S. Loss of CD127 \& increased immunosenescence of T cell subsets in HIV infected individuals. Indian J Med Res. 2011;134:972-81.

81. Nemeth CL, Bekhbat M, Neigh GN. Neural effects of inflammation, cardiovascular disease, and HIV: parallel, perpendicular, or progressive? Neuroscience. 2015;302:165-73.

Publisher's Note Springer Nature remains neutral with regard to jurisdictional claims in published maps and institutional affiliations. 